\title{
Røff kirurg i diplomatiets fotspor
}

\author{
Som rykende fersk lege og mor flyttet hun til Zimbabwe og utgjorde traumeteamet \\ på et akuttmottak i Harare. Nå er hun den eneste kvinnelige kirurgen i Øst-Jerusalem. \\ Diplomatfruen Tone Hegna blir gretten hvis hun ikke får jobbe.
}

- Jeg er en enkel sjel som liker konkrete problemstillinger. Jeg liker at ting er litt uforutsigbare. Det er vel derfor jeg ble lege og kirurg, sier Tone Hegna. Hun og diplomatektemannen har på ingen måte grodd fast - noe sted. På skift får jobbene deres bestemme hvor familien på fire skal bo, og hvor lenge de skal bo der. Men når det er diplomatjobben som bestemmer, blir ikke kona hjemmeværende diplomatfrue av den grunn.

- Diplomatfruer er nok en utdøende rase.

Tone Hegna er hjemme på sommerferie, og foreslår at vi treffes på Litteraturhuset i Oslo. Hun rekker et par timers prat der før nattevakten på Kirurgisk avdeling på Akershus universitetssykehus kaller. Sommerferien tilbringes delvis der og delvis på hytta. Hun har vokst opp på Kongsberg med to søstre, en sykepleiermor og en tannlegefar. Hun har alltid likt seg på sykehus, og kan fortsatt kose seg når hun går rundt i korridorene om natten. Da turnustjenesten sto for tur, ville hun lengst mulig vekk fra Oslo. Det ble sykehustjeneste på Gjøvik og distriktstjeneste i Kvæfjord i Troms.

- Jeg likte meg godt i Kvæfjord, selv om det ble litt ensomt. Jeg kjente bare ham i videobutikken. Men det å dra ut på hjemmebesøk, kommandere ut ferjen og langt om lenge komme frem til pasienten som gjerne sa: «Unnkyld at æ ringer doktor'n på en søndag» selv om han satt der blå i fjeset, det var fint. Ikke mye dikkedikk der, nei.

\section{The less horrible}

Tone Hegna er ikke dikkedikk-typen selv heller. Rett etter turnus tok hun med seg tre uker gamle Ebba og dro etter mannen, som da var blitt utstasjonert for FN i Zimbabwe. Etter noen måneder i landet fikk hun seg jobb ved akuttmottaket ved Parirenyatwa Hospital i Harare.

- Sykehuset gikk under navnet «The less horrible». Det var ikke så bra standard ved sykehusene der, kan du si. Jeg var aldri på «the horrible one», men det var ille nok der jeg var. Det ble en brå overgang, minnes hun.

Halvparten av pasientene har hiv eller aids. Likevel er de ansatte slepphendte med hygienen, og sprøytespisser stikkes i madrassen etter bruk. Utenfor sykehuset ligger det folk overalt, gjerne i dagevis, i håp om en konsultasjon. Mange dør i køen.
- Jeg husker første dagen jeg var der. Traumealarmen gikk og jeg sto og ventet på traumeteamet. Men det kom ingen. Traumeteamet var meg. Da følte jeg meg ikke høy $i$ hatten. Men etter hvert skjønte jeg at det jeg gjorde var mye mer enn de var vant til det var dét eller ingenting. Og heldigvis hender det at det kommer flere som kan bidra, noe som kan være greit når katastrofealarmen går omtrent en gang $i$ uken.

En trafikkulykke i Zimbabwe er ikke som en trafikkulykke i Norge. Det er gjerne ti mann på lasteplanet og ti på taket. Prioritering $\mathrm{i}$ helsevesenet har også helt andre dimensjoner når kaoset herjer og én lege står midt blant 20 hardt skadede pasienter.

- Da er det triage. De som ikke kan reddes, dem legger man til side. Mannen min husker dagen jeg kom hjem og utbrøt: «I dag var det ingen som døde på vakten min!» I Norge er det katastrofe hvis noen dør fra deg i akuttmottaket.

\section{Rottegift i barna}

President Robert Mugabe gjorde ikke hverdagen bedre. Tone Hegna og familien merket godt forverringen i løpet av det to år lange oppholdet. Den omstridte landreformen ble satt i verk, og det ble hungersnød. På sykehuset ble det mindre og mindre tilgjengelig utstyr samtidig som Mugabes politiske motstandere stadig oftere trengte sykehusbehandling. Etter hvert fylte den norske kirurgen garderobeskapet sitt med et lite nødlager medisiner. I tillegg til hansker hadde hun diverse akuttmedisiner, som for eksempel ampuller med atropin. $\AA$ se barn dø av rottegift ble for tøft.

- Rottegiften i Zimbabwe ligger overalt, i hus og hytter, gjerne blandet inn i korn og liknende. Det kan se fristende ut for små barn. Gang på gang kom det barn som hadde fătt i seg dette, og det å gå tom for ampuller og måtte stå og se på at barnet døde, det orket jeg ikke, sier hun.

Det var valgkamp, unntaktstilstand og mye tortur - det siste så Tone Hegna stadig resultatet av i akuttmottaket. Hun måtte ha spesialtillatelse hver dag for å kunne gå på jobb. I oktober 2000 ble situasjonen i landet så ille at FN beordret sine ansatte hjem. Tone skulle gjerne vært der lenger, bidratt med mer.
- Vi har fremdeles et sentimentalt forhold til Afrika.

\section{Kaféliv i New York}

FN sendte dem fra Afrika til Amerika. New York skulle være mer familievennlig ektemannen på jobb i FN-bygningen, datteren i barnehagen og Tone som litt mutt hjemmefrue. Å få jobb som utenlandsk lege i USA er tidkrevende og tilnærmet umulig.

- Manhattan er et fantastisk sted å bo, men jeg er skikkelig dårlig til å være hjemmeværende. Jeg blir gretten. Det har noe med identitet å gjøre, det å ha et yrke der du bruker mye av deg selv, tid og engasjement. - Så hvordan fikk du tiden til å gå?

- Nei, si det? Jeg likte godt å sitte på kafé og lese bøker, gå på museer og gå tur i Central Park. Og så fikk jeg jo en sønn da. En amerikaner, smiler hun.

Den lille amerikaneren Jonas ble født $i$ et av de verste slumstrøkene i New York City, så langt opp på Manhattan som det er mulig å komme. I motsetning til de fleste andre utlendinger med forsikring valgte Tone Hegna å føde i Bronx. Igjen var det tilfeldigheter som styrte. Hun så et skilt med «svangerskapskontroll» ikke langt fra der de bodde, hvorfor ikke gå inn der. Det viste seg at svangerskapskontrollen soknet til en underavdeling av sykehuset New York Presbytarian Hospital, lokalisert i et svært belastet strøk. Man beveger seg ikke utendørs her om kvelden, og alle spedbarna har alarm rundt ankelen.

- Men det gikk jo helt fint! Mannen min rakk ikke fødselen, så da taxien endelig kom frem, ville han bidra litt han også ved å passe på at ungen ikke ble borte eller forvekslet. Da sa en av jordmødrene: «Do you see any caucations here?» Sønnen vår var den eneste hvite babyen, så sannsynligheten for at han skulle bli forvekslet var ikke så stor, ler Tone.

\section{9/11}

11. september 2001 var en rolig morgen hjemme hos familien Hegna Lindbæk. Far leverte datteren $i$ barnehagen og tok undergrunnen på vei til jobben. De fikk beskjed om å gå av ved 42. gate på grunn av «en hendelse ved World Trade Center». Det kunne være så mangt, så folk gikk rolig av og ruslet den siste biten. Men fra kontoret i FN-byg- 


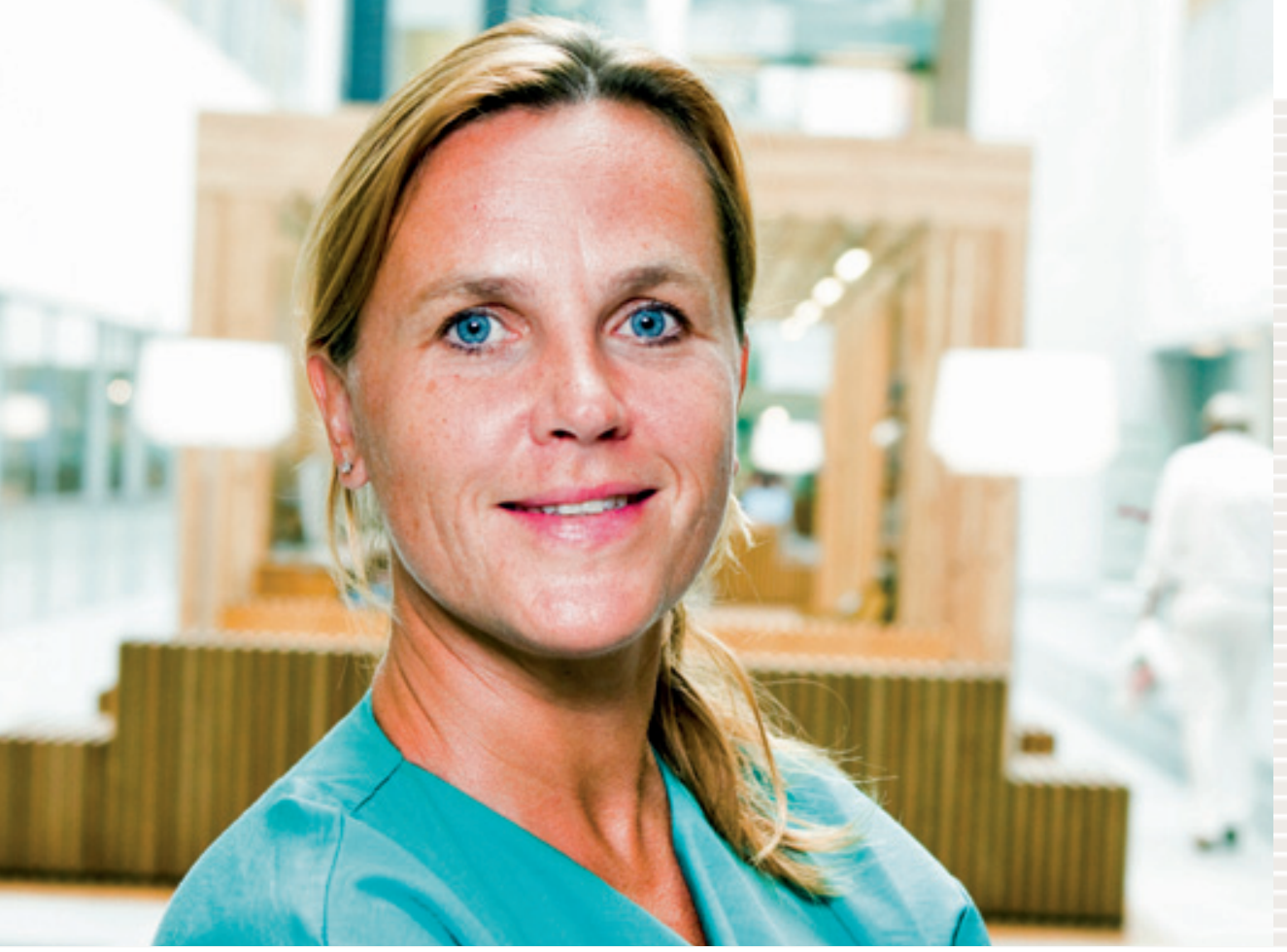

\section{Tone Olaug Aarholt Hegna \\ Født 1968}

- Cand.med. Universitetet i Oslo 1996

- Assistentlege, Kirurgisk avdeling, Akershus universitetssykehus

- Kirurg, Augusta Victoria Hospital

- Casualty officer, akuttmottaket ved Parirenyatwa Hospital, Zimbabwe 1998-2000

Tone Hegna. Foto Berit Roald/SCANPIX ningen ringte Espen Lindbæk kona og fortalte at et fly hadde kjørt inn i et av tvillingtårnene. Da han kom tilbake til vinduet hadde det samme skjedd igjen. FN-bygningen ble evakuert og kaoset var i gang.

- For oss ble det en fin gå-tidlig-hjemfra-jobben-dag. Vi skjønte jo ikke alvoret på det tidspunktet. I dagene etterpå ble det en veldig spesiell stemning i byen, med alle savnet-lappene, naboer som gikk i begravelser og folk som sto på gatehjørnene og tente lys og sang Amazing Grace. Det var ingen fly på himmelen og i det hele tatt en spøkelsesaktig stemning.

- Vurderte dere å dra hjem til Norge?

- Nei, aldri. Vi tilpasser oss bare, akkurat som vi gjør i Jerusalem nå. Vi er uansett ikke målet for terroristene. Det er farligere å kjøre bil på E6 fra Oslo til Lillehammer.

Etter to år i USA var det Tones tur til å velge land. Nå ville hun være hjemme og fullføre spesialistudanningen sin. Det ble Oslo og Norge i seks år, først Oslo legevakt og deretter Akershus universitetssykehus, Kirurgisk avdeling. Her står hun fremdeles på vaktlisten, selv nå som hun bor i Øst-Jerusalem. Er det mye vakanser, tar hun nattflyet hjem og tar et par vakter. I ferier er hun fast på plass. All erfaring er god erfaring.

\section{Kommer pasienten?}

Ved Augusta Victoria Hospital i Øst-Jerusalem jobber hun ulønnet. Den blonde damen er et eksotisk innslag som eneste kvinnelige kirurg i mils omkrets. Det er et vanskelig sted å bo, midt i en sørgelig konflikt som kun har tapere. I Jerusalem er alt politikk, det er slitsomt.

- Jeg jobber på et palestinsk sykehus i Øst-Jerusalem, og prøver å lære meg litt arabisk. For noen har jeg da tatt side. Det handler mye om å ta side her. Men jeg mener det er flere sider av en sak, jeg ser jo at alle parter lider. Det er uansett ikke min jobb å ta side. Jeg utøver faget mitt der vi er stasjonert og forsøker bare å gjøre en liten forskjell for de pasientene jeg møter, sier Hegna.

Augusta Victoria er ett av fem palestinske sykehus i Øst-Jerusalem, og det eneste som tilbyr strålebehandling og kreftkirurgi til den palestinske befolkningen. Det spesielle er at sykehuset ligger i Øst-Jerusalem mens alle pasientene er på Vestbredden og Gaza. Palestinerne som bor i byen, har såkalt Jerusalem-ID og behandles i det israelske helsevesenet. De som bor utenfor, må gjennom muren og grensekontrollene for å komme seg til sykehus. Det byr ofte på problemer.

- Vi skal dekke fire millioner pasienter, men sitter ofte og venter fordi de ikke har fătt papirene i orden eller blir stoppet på veien. Det er sørgelig.

Hun forteller at det kan ta flere måneder å få papirene til operasjon i orden. Behandlingen skal godkjennes både fra palestinsk og israelsk side. Hvis noe skjærer seg i systemet, kan det ta lang tid før de får en ny sjanse. Det kan koste dyrt for kreftpasienter.

- Det gjør meg opprørt når folk ikke får den behandlingen de skal ha, enten det er kreftpasienter eller andre.

Strømbrudd er en stor utfordring i hverdagen som lege. De er relativt hyppige og av ulik varighet.

- Når strømmen går midt i en operasjon og anestesipanelet blir svart, da holder vi pusten. Skal vi starte med manuell ventilasjon eller vente på strømmen? Vi har hatt tilfeller med ti strømbrudd på kort tid, opp og ned med lommelykten. Da kobler vi ut strømmen selv og holder oss til aggregatet.

\section{Rypejakt og egen smøreteknikk}

Erfaringen setter ting i perspektiv. Norske kolleger klager ofte på ubetydeligheter. En kollega beskriver Tone Hegna som målbevisst, kjapp og en som bruker lite tid på perfeksjonering.

- Jeg er litt utålmodig av meg, generelt.
Jeg tar beslutninger raskt og går for det, forklarer hun.

Tone Hegna er rask på avtrekkeren også, og går gjerne på rypejakt. Noen fare for bestanden er hun imidlertid ikke, for rypejakt uten hund er visst ikke så effektivt. Fjell og friluftsliv er familiens favorittfritidssyssel, og turen må ha et mål, enten det er å jakte på ryper, plukke sopp og bær eller ta bilder. Kondomdress og pulsklokke er ikke denne damens stil, og i skiløypene har hun sin egen smøreteknikk. Hun smører utenpå fjorårets og forfjorårets.

- Men jeg har alltid de beste skiene, så det funker!

I Jerusalem er de den merkelige familien som pakker sekken og går søndagstur i skogen, i 40 varmegrader og med litt for lite vann. I verdens mest omstridte by er den norske troppen samlet i det Tone kaller suburbia, i rekkehus med hver sin lille hageflekk. Hver fredag møtes de til fredagspils og pizza. Ryktene går, så nå kommer svenskene også luskende. Ved Det norske representasjonskontoret for de palestinske områdene i Al Ram er det lite tid til mottakelser. Men det hender, og da tar fruen på skjørt og høye hæler og blir med til Vestbredden, i pansret bil. Mottakelser var det mer av i Zimbabwe, og ved én anledning satte den norske diplomatfruen landets helseminister på plass.

- Vi sto med drinkene i hånden og snakket sammen, vi fruene og helseministeren. Han la ut om hvor fint det gikk, hvor bra helsevesenet var og hvor flink han var. Til slutt kunne jeg ikke dy meg, og sa «Vet du hva? Alt du sier er feil! Det finnes ikke medisiner, det finnes ikke utstyr og vi får ikke behandlet pasientene. Det er tragisk og ille og fælt!» Helseministeren ble skikkelig snurt og bare gikk. Sånn kan det gå. Jeg er jo ikke særlig diplomatisk av meg.

\section{Eline Feiring}

eline.feiring@legeforeningen.no Tidsskriftet 